\title{
The association of haemagglutination and adhesion with lipopolysaccharide of Shigella dysenteriae serotype 1
}

\author{
F. QADRI*, S. HAQ, S. A. HOSSAIN, I. CIZNAR and S. TZIPORI \\ International Centre for Diarrhoea/ Disease Research, GPO Box 128, Dhaka 1000, Bangladesh
}

\begin{abstract}
Summary. In this study the ability of strains of Shigella dysenteriae serotype 1 to agglutinate mammalian erythrocytes is attributed to the polysaccharide fraction of bacterial-cell lipopolysaccharide (LPS). LPS obtained from a rough, mutant strain of $S$. dysenteriae serotype 1, lacking the $\mathrm{O}$-antigen polysaccharide side-chain, did not agglutinate erythrocytes, clearly demonstrating a link between O-antigen polysaccharides and haemagglutinating activity (HA). Strains of $S$. dysenteriae serotype 1 adhered well to cultured Henle Intestinal 407 cells, whereas rough strains adhered poorly. Pre-treatment of bacteria with LPS-specific antisera inhibited both HA and binding to cultured human-intestinal cells. The contribution of the polysaccharide side-chain and its associated HA - which appear to facilitate binding to cultured cells - to bacterial attachment to colonocytes and to the pathogenesis of shigellosis in vivo needs to be confirmed in animal studies.
\end{abstract}

\section{Introduction}

Shigella dysenteriae serotype 1 , the most pathogenic type of Shigella, is responsible for major epidemics of bacillary dysentery in developing countries. ${ }^{1,2}$ The ability to invade and multiply within host colonicepithelial cells is pathognomonic of shigellae. ${ }^{3}$ Additional factors contributing to virulence may include lipopolysaccharide (LPS), outer-membrane proteins (OMPs) and Shiga toxin, although their precise relative roles are far from clear.

Bacterial adhesion to epithelium of mucosal surfaces is an essential step in the pathogenesis of many diseases, including enteric infections. ${ }^{4}$ This process is mediated by fimbriae, flagella, capsule, glycocalyx, LPS, non-fimbrial adhesin or lectin. ${ }^{5,6}$ The attachment of Shigella strains to host cells has been reported; strains of $S$. flexneri serotype $1 \mathrm{~b}$ adhere to guinea-pig colonic cells ${ }^{7}$ and strains of $S$. flexneri serotype 5 to HeLa cells. ${ }^{8}$ We have shown recently that strains of $S$. dysenteriae serotype 1 and $S$. flexneri agglutinate mammalian erythrocytes, and that haemagglutination (HA) was resistant to D-mannose and sensitive to $N$ acetylneuraminic acid, $N$-acetylneuraminlactose, and $\alpha_{1}$-glycoprotein. Fimbriae were observed by electronmicroscopy in strains of $S$. dysenteriae serotype 1 that were haemagglutinating. ${ }^{9}$ In the present study we have characterised the haemagglutinin of $S$. dysenteriae serotype 1 and examined its relationship to adherence of bacteria to cells cultured in vitro.

Received 7 Aug. 1990; accepted 7 Sep. 1990.

*Correspondence to Dr F. Qadri.

\section{Materials and methods}

\section{Bacterial strains}

Shigella strains included in the study were obtained from the diarrhoeal faeces of patients attending the Clinical Research Centre (CRC) of the International Centre for Diarrhoeal Disease Research, Bangladesh (ICDDR, B), Dhaka. Strain 14731 of $S$. dysenteriae serotype 1 was used for extraction of cell-surface components, and results were confirmed with three other strains (12588, 3351 and 26406). A nonpathogenic strain, 36000, of Escherichia coli of serotype O8:K25 and a rough mutant strain, 60R, of $S$. dysenteriae serotype 1 were obtained from the Centers for Disease Control, Atlanta, GA, USA. Another rough mutant, strain PSD-10, of $S$. dysenteriae serotype $1^{10}$ was obtained from Dr K. Haider (ICCDR, B). Sereny's test ${ }^{11}$ and Congo-red binding assay ${ }^{12}$ were used to confirm the virulence of strains.

\section{Media and storage}

Bacteria stored at $-70^{\circ} \mathrm{C}$ were subcultured on trypticase soy (TS) agar and grown in Casamino acidyeast extract (CYE) broth in the presence of $1 \mathrm{~mm}$ calcium chloride for $22 \mathrm{~h}$ at $37^{\circ} \mathrm{C}$ to express $\mathrm{HA}$ properties. ${ }^{9}$ Bacteria were grown either in screwcapped test-tubes containing $5 \mathrm{ml}$ of medium for $\mathrm{HA}$ expression, or in 500-ml bottles (Gibco Diagnostics, Madison, WI, USA) containing $150 \mathrm{ml}$ of medium for extraction of bacterial components. 


\section{HA assays}

These were performed on slides, ${ }^{9}$ or in U-bottomed microtitration plates (Cooke, Alexandria, VA, USA) with erythrocytes $0.5 \% \mathrm{v} / \mathrm{v}$. Equal volumes $(30 \mu \mathrm{l})$ of doubling dilutions of bacterial components and guinea-pig erythrocytes were mixed, and plates were sealed and incubated for $1 \mathrm{~h}$ at room termperature with shaking $(160 \mathrm{rpm})$ on a rotary shaker. Results were recorded after $30 \mathrm{~min}$ and scored as positive, when the erythrocyte suspension was distributed over the bottom of the wells, or as negative when a red button was clearly visible. Titres were recorded as the arithmetic mean of the minimum concentration of material at which HA was clearly visible. HA was tested with guinea-pig, human (types A, B, O), monkey, rabbit and sheep erythrocytes. ${ }^{9}$ However, in most assays guinea-pig and human (type $\mathrm{O}$ ) erythrocytes only were used.

\section{Inhibition of $H A$}

Inhibition of HA was tested with $N$-acetylneuraminic acid (Sigma) $1 \% \mathrm{w} / \mathrm{v}$, fetuin (from fetal calf serum, Sigma) $1 \% \mathrm{w} / \mathrm{v}$ and other carbohydrates. ${ }^{9}$ Inhibition by LPS-specific rabbit antibody was tested after incubation with test material for $1 \mathrm{~h}$ at $37^{\circ} \mathrm{C}$.

\section{Extraction and purification of bacterial components}

To determine whether in strains of $S$. dysenteriae serotype $1 \mathrm{HA}$ was mediated by protein, extraction methods used for $E$. coli were utilised. ${ }^{13,14}$ For isolation of haemagglutinin, OMPs were also prepared by either a lysozyme and EDTA-extraction procedure, ${ }^{15}$ or a simple buffer-extraction technique. ${ }^{16}$ LPS was extracted with hot phenol-water, ${ }^{17}$ and purified by ultracentrifugation at $100000 \mathrm{~g}$ for $4 \mathrm{~h}$. Nucleicacid contaminants in LPS $(5-10 \mathrm{mg} / \mathrm{ml})$ were removed by treatment with DNAase and RNAase (Sigma) $20 \mu \mathrm{g} / \mathrm{ml}$, and protein contaminants by treatment with proteinase K (Sigma) $100 \mu \mathrm{g} / \mathrm{ml}$. LPS was collected by centrifugation at $100000 \mathrm{~g}$ for $4 \mathrm{~h}$.

\section{Delipidation of LPS}

LPS from strains of $S$. dysenteriae serotype 1 was delipidated ${ }^{18}$ by refluxing in acetic acid $1 \% \mathrm{v} / \mathrm{v}$. The aqueous layer was lyophilised, resuspended in water and centrifuged at $100000 \mathrm{~g}$ for $4 \mathrm{~h}$ to remove unhydrolysed LPS. After lyophilisation of supernate, polysaccharide was chromatographed on BioGel P10. Eluates were collected and analysed by the phenolsulphuric acid test. ${ }^{19}$ Polysaccharide fractions were pooled, dialysed and lyophilised.

Cell debris from bacteria grown in CYE medium was removed by centrifugation at $8000 \mathrm{~g}$ for $30 \mathrm{~min}$. The clear culture supernate was collected, passed through a membrane filter $(0.45 \mu \mathrm{m}$, Millipore), dialysed for $24 \mathrm{~h}$ against deionised water and lyophil- ised. Culture supernates prepared in this manner are referred to as "CS" hereafter. Uninoculated culture medium, treated as above, was used as control.

Components used in HA assays described below were freeze-dried and reconstituted in PBS. Protein estimation was by the dye-binding method, ${ }^{20}$ and carbohydrate content in LPS was determined by the phenol-sulphuric acid method. ${ }^{19}$ Purified LPS and other LPS-containing fractions were quantified on the basis of carbohydrate content rather than dry weight. To confirm further the presence of LPS, the content of 2-keto-3-deoxy-octulonate (KDO), a core sugar in LPS, was estimated. ${ }^{21}$ LPS was also detected in fractions by the Chromogenic Limulus Amoebocyte Lysate (LAL) method (Whittaker Bioproducts Inc., Walkersville, MD, USA) with LPS from $E$. coli serotype O55:B5 used as standard. ${ }^{22}$ Sialic-acid content in materials was assayed ${ }^{23}$ with $N$-acetyl neuraminic acid as standard.

\section{Gel filtration}

Culture supernates were fractionated on columns $(74 \times 2 \mathrm{~cm}$ ) of Sepharose 4B (Pharmacia Fine Chemicals, Uppsala, Sweden). The elution volume was $108 \mathrm{ml}$ for Blue Dextran (Pharmacia) and $118 \mathrm{ml}$ for LPS from strains of $S$.dysenteriae serotype 1 . Fractions were assayed for protein (OD at $280 \mathrm{~nm}$ ) and for carbohydrate content. ${ }^{19}$ Fractions were pooled, lyophilised and tested for HA activity.

\section{Enzyme treatment}

Suspensions of $S$. dysenteriae serotype $1(1 \times$ $\left.10^{10} \mathrm{cfu}\right)$ in PBS $(0.5 \mathrm{ml})$ were treated with trypsin (Flow Laboratories, Herts) $50 \mu \mathrm{g}$ or proteinase $\mathrm{K}$ $100 \mu \mathrm{g}$ and incubated for $4 \mathrm{~h}$ at $37^{\circ} \mathrm{C}$. Culture supernates and LPS were treated similarly.

Guinea-pig erythrocytes $(50 \% \mathrm{v} / \mathrm{v})$ were treated with 100-1000 milli-units of neuraminidase from Clostridium perfringens (Sigma) and incubated, as described above, before testing in HA assays.

\section{Antibodies}

New Zealand white rabbits were immunised by two subcutaneous doses of CS $(100 \mu \mathrm{g})$ mixed with Freund's complete adjuvant, given at a 10-day interval, followed by a third dose $(150 \mu \mathrm{g})$, given 15 days later. Serum was collected 1 week after the last injection and stored at $-20^{\circ} \mathrm{C}$. The rabbit-antibody titre to LPS of $S$. dysenteriae serotype 1 (anti-CS) was determined by ELISA $^{2}$ with LPS purified from $S$. dysenteriae serotype $1(25 \mu \mathrm{g} / \mathrm{ml})$ used as source of antigen; the titre was $2.56 \times 10^{4}$. For absorption studies, serum $(1 \mathrm{ml})$ was incubated with LPS of $S$. dysenteriae serotype 1 ( $3 \mathrm{mg}$ ) for $1 \mathrm{~h}$ at $37^{\circ} \mathrm{C}$ and then overnight at $4^{\circ} \mathrm{C}$. After incubation, the absorbed serum was centrifuged at $35000 \mathrm{~g}$. Convalescent sera, collected 21 days after 
onset of infection in three adult patients infected with $S$. dysenteriae serotype 1, were also included in the study.

\section{Crossed immuno-electrophoresis and double immunodiffusion}

Crossed immuno-electrophoresis ${ }^{24}$ was performed on glass plates $(5 \times 5 \mathrm{~cm})$ with agarose $1 \% \mathrm{w} / \mathrm{v}$ in Tricine buffer ( $\mathrm{pH} 8.7)$. Double immunodiffusion was performed according to the method of Ouchterlony ${ }^{25}$ on glass microscope slides.

\section{Bacterial adhesion to cultured epithelial cells}

Henle Intestinal 407 cells (Int. 407) (Flow Laboratories) were maintained in Basal Eagle's Medium (Flow) supplemented with newborn calf serum (Flow) $15 \% \mathrm{v} / \mathrm{v}$ and $2 \mathrm{mM}$ glutamine. Cells were seeded $(1 \times$ $10^{5}$ ) in culture vials (Kimble, Toledo, OH, USA) containing cover slips (12-mm diameter). After $18 \mathrm{~h}$, cells were inoculated with bacterial suspensions $(100 \mu \mathrm{l})$ containing $1 \times 10^{9} \mathrm{cfu}$ and centrifuged at $500 \mathrm{~g}$ for $10 \mathrm{~min}$ at $4^{\circ} \mathrm{C}$. The vials were incubated for a further $20 \mathrm{~min}$ at $37^{\circ} \mathrm{C}$ in air $+\mathrm{CO}_{2} 5 \%$ and washed $(\times 10)$ by aspiration with PBS to remove non-adherent bacteria. Cover slips were fixed in methanol, stained with Giemsa and examined by oil-immersion microscopy $(\times 1000)$. Adhesion and invasion were also confirmed by performing quantitative bacterial counts. ${ }^{26}$ Both smooth virulent (Congo-red positive) and rough mutant strains of $S$. dysenteriae serotype 1 were examined in adhesion assays (table II). The effect of serum, bacterial components, carbohydrates, proteins, and enzymes on the adhesion of bacteria to Int. 407 cells was determined (table III). For each assay bacteria adhering to 10 infected cells were counted and the number of bacteria adhering per cell was calculated. The mean and SEM of bacteria adhering per cell from five separate experiments were calculated. Extent of adhesion under different conditions was expressed as the percentage of binding compared to that of the smooth, virulent control strain 14731. Student's $t$ test was used to calculate differences in adhesion due to the effect of various pre-treatments; $p$ values $>0.05$ were considered to be not significant.

\section{Bacterial adhesion to immobilised mucin}

Human mucin (extracted from a human colon at necropsy) was fractionated $(20 \mathrm{mg} / \mathrm{ml})$ on a column $(2.2 \times 36 \mathrm{~cm})$ of Sepharose 4B. Fractions eluting in the region of Blue Dextran $(60 \mathrm{ml})$ were dialysed against PBS and lyophilised. For immobilisation purposes, $0.5 \mathrm{ml}$ of human mucin $(1.5 \mathrm{mg} / \mathrm{ml})$ was immobilised ${ }^{27}$ on culture vials containing cover slips. Adhesion assays with bacteria were performed as described above and adhesion was expressed as the number of adherent bacteria per $\mathrm{mm}^{2}$.

\section{Results}

\section{Extraction and purification of haemagglutinin}

The OMPs and cell-surface proteins of strain 14731 of $S$. dysenteriae serotype 1, prepared by different methods, did not agglutinate erythrocytes in protein concentrations of $\leqslant 10 \mathrm{mg} / \mathrm{ml}$, either on slides or in microtitration plates. Treatment of haemagglutinating bacteria with trypsin or proteinase $\mathrm{K}$ had no effect on HA nor did pre-treatment of erythrocytes with neuraminidase.

Culture supernates of strain 14731 of $S$. dysenteriae serotype 1 caused HA at concentrations of $\geqslant 52.6 \mu \mathrm{g} /$ $\mathrm{ml}$ (table I). Heating of $\mathrm{CS}$ at $100^{\circ} \mathrm{C}$ for up to $30 \mathrm{~min}$ or treatment with trypsin or proteinase $\mathrm{K}$ had no effect on HA. When CS was fractionated through a column of Sepharose 4B, HA $(30.6 \mu \mathrm{g} / \mathrm{ml})$ was detected in materials eluting (Pool-1, fractions $90-115 \mathrm{ml}$ ) at a volume similar to the region at which LPS $(118 \mathrm{ml})$ from $S$. dysenteriae serotype 1 was eluted. Subsequent fractions (230-380) did not contain HA activity. Pool1 contained a high concentration of carbohydrates $(1.05 \mathrm{mg} / \mathrm{ml})$ but a relatively low concentration of protein $(0 \cdot 126 \mathrm{mg} / \mathrm{ml})$. Pool-1 showed a reaction of identity with LPS when analysed by double immunodiffusion by Ouchterlony's method against rabbit antiCS serum. CS, Pool-1 and LPS showed similar precipitin lines when analysed against rabbit anti-CS serum by crossed immuno-electrophoresis. Pool-1 gave a positive reaction with thiobarbituric acid confirming the presence of KDO and was positive in the LAL assay indicating the presence of endotoxin (at $\leqslant 50 \mathrm{pg} /$ $\mathrm{ml})$. Heat treatment or treatment with proteolytic

Table I. Haemagglutinating activity (HA) of bacterial components of $S$. dysenteriae serotype 1 strain 14731 and LPS of other strains

\begin{tabular}{|c|c|c|}
\hline Bacterial component & HA & $\begin{array}{l}\text { Minimum concentration } \\
\text { required for } \mathrm{HA} \\
(\mu \mathrm{g} / \mathrm{ml})^{*}\end{array}$ \\
\hline Culture supernate & + & 52.6 (SEM 3) \\
\hline Sepharose 4B eluate (Pool-1) & + & 30.6 (SEM 1.8) \\
\hline LPS (from $S$. dysenteriae serotype & + & 18.58 (SEM 1.01) \\
\hline $\begin{array}{l}\text { Polysaccharides (from delipida- } \\
\text { tion of LPS) }\end{array}$ & + & 3.98 (SEM 0.152) \\
\hline $\begin{array}{l}\text { LPS (from strain } 36000 \text { of } E . \text { coli } \\
\text { serotype O8:K25) }\end{array}$ & $-\dagger$ & $\cdots$ \\
\hline $\begin{array}{l}\text { LPS (from a strain of E. coli } \\
\text { serotype O55:B5) }\end{array}$ & - & $\ldots$ \\
\hline $\begin{array}{l}\text { LPS (from strain } 6577 \text { of } S \text {. } \\
\text { sonnei form 1) }\end{array}$ & - & $\cdots$ \\
\hline $\begin{array}{l}\text { LPS (from strain } 33744 \text { of } S \text {. } \\
\text { boydii serotypes 1-6) }\end{array}$ & - & $\ldots$ \\
\hline $\begin{array}{l}\text { LPS (from rough mutant strain } \\
\text { PSDIO) }\end{array}$ & - & $\ldots$ \\
\hline $\begin{array}{l}\text { LPS (from rough mutant strain } \\
60 \mathrm{R} \text { ) }\end{array}$ & - & $\ldots$ \\
\hline
\end{tabular}

* All materials were quantified on the basis of carbohydrate content and results shown are the mean (and SEM) of three experiments.

† Components negative for HA were tested up to a concentration of $10 \mathrm{mg} / \mathrm{ml}$. 
enzymes did not affect HA activity, results confirming that Pool-1 contained LPS.

Purified LPS obtained from strain 14731 of $S$. dysenteriae serotype 1 agglutinated erythrocytes (table I). Treatment with heat or enzymes did not decrease activity. HA activity of CS, Pool-1 and LPS (at $\leqslant 80 \mu \mathrm{g} / \mathrm{ml}$ ) was completely inhibited by rabbit antiCS serum (at a dilution of 1 in 100 in PBS). However, serum absorbed with LPS did not inhibit the HA of these preparations, results confirming that HA in cellfree cultures of $S$. dysenteriae serotype 1 was associated with LPS. Similar results were obtained with CS and LPS derived from haemagglutinating strains 12588 , 3351 and 26406 of $S$. dysenteriae serotype 1.

Pre-treatment of LPS, CS and Pool-1 with $N$-acetyl neuraminic acid or fetuin resulted in loss of HA activity. Polysaccharides obtained by delipidation of LPS showed highest HA activity (table I). LPS obtained from $S$. sonnei, $S$. boydii, rough mutant strains (PSD-10, 60R) of $S$. dysenteriae serotype 1, $E$. coli serotype O55:B5 or a non-pathogenic strain of E. coli serotype 08:K25 did not show HA activity (table I).

Bacterial cultures, PBS extracts, CS and LPS did not contain sialic acids when tested by the resorcinol$\mathrm{HCl}$ method. ${ }^{23}$

\section{Adhesion to Int .407 cells}

When incubated with Int.407 cells for $20 \mathrm{~min}$ at $37^{\circ} \mathrm{C}$, haemagglutinating strains of $S$. dysenteriae serotype 1 showed adherence (table II) (fig. 1b). When incubation of bacteria with Int. 407 cells was allowed to progress longer, cell invasion occurred (fig. 1c). Int. 407 cells, grown for $18 \mathrm{~h}$ on coverslips, were better suited for this assay than cells grown for $\geqslant 40 \mathrm{~h}$. Smooth (Congo-red positive) virulent strains adhered to Henle 407 cells; in contrast, rough mutant strains of $S$. dysenteriae serotype 1 bound poorly (table II).

Binding of strains of $S$. dysenteriae serotype 1 to Int. 407 cells was completely inhibited by pre-treatment of cells with homologous LPS (table III) at $0.18 \mathrm{mg} / \mathrm{ml}$. CS at a similar concentration inhibited $c$. $60 \%$ of adherence. Human convalescent sera and rabbit anti-CS serum also inhibited, to some extent, bacterial adhesion. When Int. 407 cells were treated with wheat-germ agglutinin, binding of bacteria was reduced by $84 \%$. Neuraminidase treatment of intestinal cells also reduced considerably the numbers of bound bacteria. However, the presence of human mucin increased binding of bacteria to Int. 407 cells (174\%). Thus, various pre-treatments (table III) significantly affected the adhesion of $S$. dysenteriae serotype 1 to Int .407 cells ( $\mathrm{p}$ values, $\leqslant 0 \cdot 01$ ).

Table II. Adhesion to Int.407 cells by strain 14731 of $S$. dysenteriae serotype 1 and by rough mutant strains

\begin{tabular}{l|ccc}
\hline \multicolumn{1}{c|}{ Strain no. } & $\begin{array}{c}\text { Number (SEM) } \\
\text { of adherent } \\
\text { bacteria/cell* }\end{array}$ & $\begin{array}{c}\text { Adhesion } \\
\text { (percentage of } \\
\text { control) }\end{array}$ & p value \\
\hline 14731 (control) & $75.8(7.05)$ & 100 & \\
Rough mutant PSD-10 & $12.8(2.59)$ & 16.9 & $<0.01$ \\
Rough mutant 60R & $15.2(3.84)$ & 20.0 & $<0.01$ \\
\hline
\end{tabular}

* Results are expressed as mean (and SEM) of five experiments.
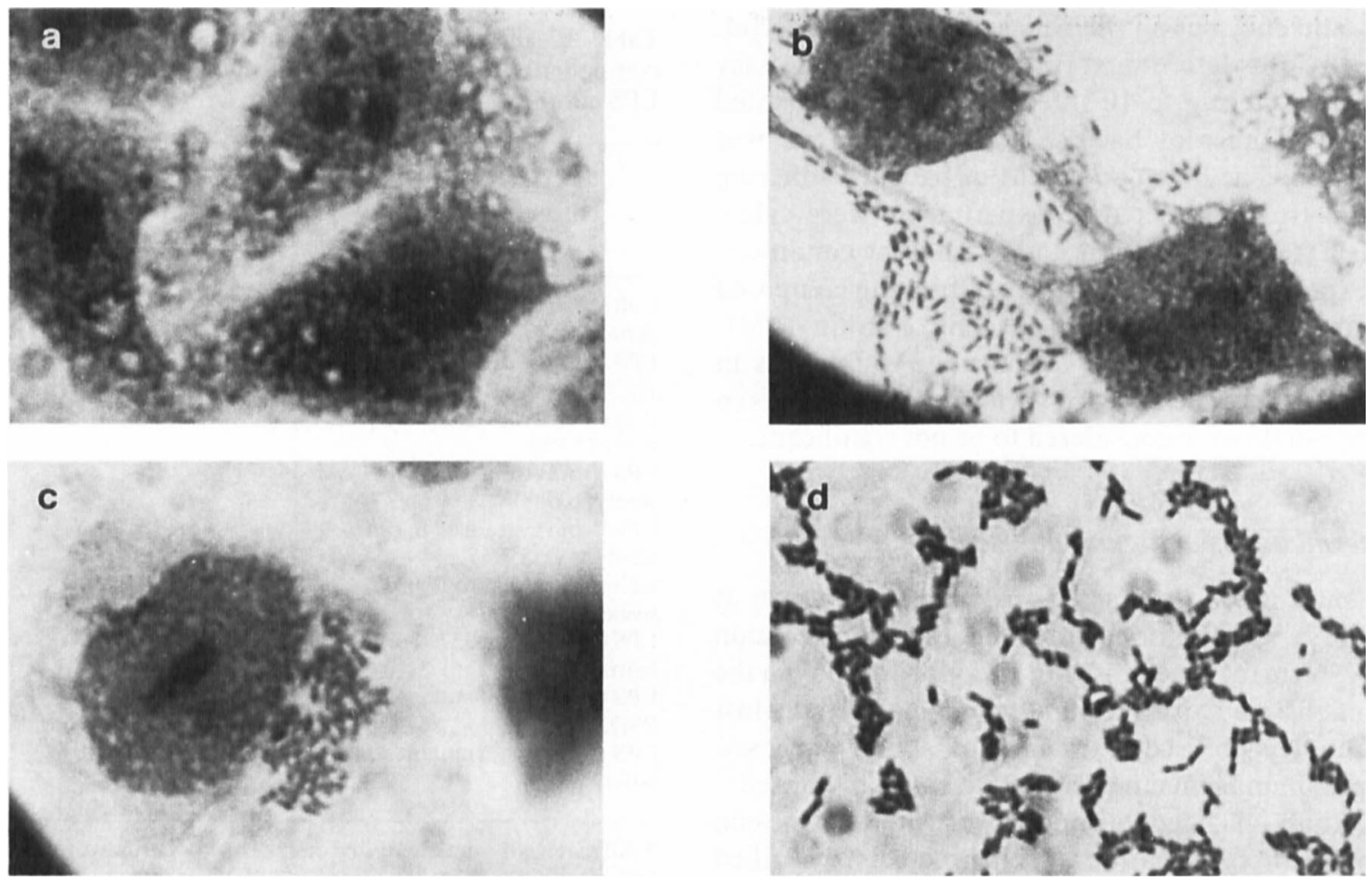

Fig. 1. Uninoculated (control) cells of Int.407 (a); and, after incubation with strain 14731 of $S$. dysenteriae serotype 1, showing adhesion after $20 \mathrm{~min}(\mathbf{b})$ and invasion after $3 \mathrm{~h}(\mathbf{c})$; binding to immobilised mucin is also shown (d). 
Table III. Effect of various pre-treatment regimens on adhesion of strain 14731 of $S$. dysenteriae serotype 1 to Int. 407 cells

\begin{tabular}{|c|c|c|c|}
\hline Pre-treatment & $\begin{array}{c}\text { Concen- } \\
\text { tration } \\
(/ \mathrm{ml})\end{array}$ & $\begin{array}{l}\text { Adhesion } \\
\text { (percentage } \\
\text { of control)* }\end{array}$ & $\begin{array}{l}\text { Difference } \\
\text { from control } \\
\text { (p value) }\end{array}$ \\
\hline $\begin{array}{l}\text { Neuraminidase } \\
\text { Wheat-germ agglutinin } \\
\text { Mucin (human) } \\
\text { LPS ( } \text {. dysenteriae sero- } \\
\text { type } 1 \text { ) } \\
\text { Culture supernate } \\
\text { Rabbit (anti-CS) serum* } \\
\text { Convalescent serum from } \\
\text { patient } 1^{*} \\
\text { patient } 2 \\
\text { patient } 3\end{array}$ & $\begin{array}{c}100 \text { units } \\
0.05 \mu \mathrm{g} \\
0.05 \mu \mathrm{g} \\
0.18 \mu \mathrm{g} \\
0.18 \mu \mathrm{g}\end{array}$ & $\begin{array}{c}20 \cdot 0 \\
16 \cdot 1 \\
174 \cdot 6 \\
0 \cdot 0 \\
\\
40 \cdot 89 \\
33 \cdot 4 \\
\\
18 \cdot 46 \\
25 \cdot 1 \\
37 \cdot 9\end{array}$ & $\begin{array}{r}<0.01 \\
<0.01 \\
<0.01 \\
<0.01 \\
\\
\quad 0.01 \\
<0.01 \\
\\
<0.01 \\
<0.01 \\
<0.01\end{array}$ \\
\hline
\end{tabular}

* All sera were tested at a dilution of 1 in 50 in PBS.

\section{Binding to mucin}

Strains of $S$. dysenteriae serotype 1 also bound to immobilised human mucin (average of $1.2 \times 10^{4} / \mathrm{mm}^{2}$ ) (fig. 1d). Binding of bacteria to Int.407 cells in the presence of mucin could not be inhibited by any of the above conditions.

\section{Discussion}

The results show that HA activity of $S$. dysenteriae serotype 1 is associated with LPS present in culture supernates and with LPS purified from the bacteria. Proteins were not linked with LPS in this interaction because heat and proteases did not affect the HA activity of purified LPS or components separated from culture supernate. The observations that rabbit serum raised against $C S$ inhibited this activity, and that absorption of LPS antibodies removed this inhibition, further confirmed the role of LPS in the agglutination of erythrocytes.

The agglutination of erythrocytes by LPS from $S$. dysenteriae serotype 1 appeared to be highly specific and possibly involved the $\mathrm{O}$-antigenic carbohydrate side-chains. Polysaccharides separated from the lipid A component of LPS also agglutinated erythrocytes. It was not possible to test lipid A for HA because of its insolubility in aqueous solutions, although this component is known to have affinity for cell membranes. ${ }^{28}$ LPS extracted from rough mutant strains of $S$. dysenteriae serotype 1, that are deficient in polysaccharide side-chains, did not show agglutinating activity. Rough strains also exhibited poor adherence to Int 407 cells.

LPS derived from smooth strains inhibited adhesion of $S$. dysenteriae serotype 1 to Int. 407 cells. Izhar $e t$ $a l^{7}$ have shown that LPS from $S$. flexneri serotype $1 \mathrm{~b}$ inhibited binding of homologous strains to guinea-pig colonic cells, suggesting that bacteria adhere via LPS to a glycoprotein receptor on host tissue. Our results also indicate that the heat- and protease-resistant adhesin (for both erythrocytes and cultured epithelial cells) is associated with LPS. It has been shown before that only smooth strains of Shigella ${ }^{3,29}$ are virulent, although an exact function was not assigned to LPS. However, in Salmonella typhi, it has been shown that smooth LPS is necessary for adhesion and invasion. ${ }^{26}$ LPS obtained from strains of $S$. sonnei form $1, S$. boydii serotypes 1-6 and from $E$. coli serotypes O8:K25 or O55:B5, under the same culture conditions, did not agglutinate erythrocytes, a finding pointing perhaps to the specificity of LPS required for such activity.

HA activity of $S$. dysenteriae serotype 1 is sensitive to sialic acids and the haemagglutination ability of LPS is also sensitive to sialic acid or to fetuin obtained from fetal calf serum, a sialic acid-containing $(5.7 \%$ NANA) protein. This suggests that LPS binds to sialic acid-containing receptors on erythrocytes. The binding of protein adhesins to erythrocytes is mediated via receptors containing specific carbohydrates, including sialic acids which may, or may not, be sensitive to sialinidases such as neuraminidase. ${ }^{13,30-32}$ We have demonstrated that treatment of erythrocytes with neuraminidase from $C$. perfringens did not decrease the affinity of the haemagglutinin to erythrocytes, whereas similar treatment of cultured intestinal cells resulted in a marked decrease in binding of bacteria, as has been reported in other interactions. The reason for the resistance of erythrocytes to treatment with neuraminidase is not clear, but indicates perhaps that the enzyme has no effect on LPS-binding site. Other proteolytic and hydrolytic enzymes will have to be tested to characterise further the haemagglutininbinding site on the erythrocyte surface.

Although the association of adhesins with LPS is less common than with protein, it has been reported before. Other bacteria, the adhesins of which were shown to be LPS-associated, include Campylobacter jejuni, ${ }^{6}$ Vibrio cholerae ${ }^{33}$ S. typhi, ${ }^{26}$ and $E$. coli $\mathrm{F}-18 .{ }^{34}$ We conclude that strains of $S$. dysenteriae serotype 1 have an adhesive property which is associated with $\mathrm{O}$ antigenic polysaccharide. This study and those of Izhar et al. $^{7}$ and $\mathrm{Pal}$ and $\mathrm{Hale}^{8}$ highlight the role of adhesins in the interaction of strains of $S$. flexneri and $S$. dysenteriae serotype 1 with host-cell surfaces. The significance of bacterial adhesion in the pathogenesis of shigellosis needs to be clarified in vivo; it is possible that high titres of serospecific LPS antibody, that can be demonstrated in patients recovering from $S$. $d y$ senteriae serotype 1 and $S$. flexneri infections, ${ }^{2}$ play a major role in protection against species- and serotypespecific re-infection by preventing bacterial adhesion.

This research was supported by United States Agency for International Development (USAID) and the International Centre for Diarrhoeal Disease Research, Bangladesh (ICDDR, B). We thank Mr M. Haque for secretarial assistance. 


\section{References}

1. Binns MM. Molecular genetics of virulence in Shigella. Microbiol Sci 1985; 2: 275-278.

2. Lindberg AA, Haeggman S, Karlsson K, Cam PD, Trach DD. The humoral antibody response to Shigella dysenteriae type 1 infection, as determined by ELISA. Bull WHO 1984; 62 : 597-606.

3. Levine MM, Kaper JB, Black RE, Clements ML. New knowledge on pathogenesis of bacterial enteric infections as applied to vaccine development. Microbiol Rev 1983; 47: $510-550$.

4. Beachey EH. Bacterial adherence: adhesin-receptor interactions mediating the attachment of bacteria to mucosal surfaces. J Infect Dis 1981 ; 143: 325-345.

5. Chan R, Acres SD, Costerton JW. Morphological examination of cell surface structures of enterotoxigenic strains of Escherichia coli. Can J Microbiol 1984; 30: 451-460.

6. McSweegan E, Walker RI. Identification and characterization of two Campylobacter jejuni adhesins for cellular and mucous substrates. Infect Immun 1986; 53: 141-148.

7. Izhar M, Nuchamowitz Y, Mirelman D. Adherence of Shigella flexneri to guinea pig intestinal cells is mediated by a mucosal adhesin. Infect Immun 1982; 35: 1110-1118.

8. Pál T, Hale TL. Plasmid-associated adherence of Shigella flexneri in a HeLa cell model. Infect Immun 1989; 57: 25802582.

9. Qadri F, Haq S, Čižnár I. Hemagglutinating properties of Shigella dysenteriae type 1 and other Shigella species. Infect Immun 1989; 57: 2909-2911.

10. Haider K, Azad AK, Qadri F, Nahar S, Cižnár I. Role of plasmids in virulence-associated attributes and in $\mathrm{O}$ antigen expression in Shigella dysenteriae type 1 strains. Med Microbiol 1989; 33: 1-9.

11. Serény B. Experimental Shigella keratoconjunctivitis. Acta Microbiol Acad Sci Hung 1955; 2: 293-296.

12. Qadri F, Hossain SA, Čižnár I et al. Congo red binding and salt aggregation as indicators of virulence in Shigella species. Clin Microbiol 1988; 26: 1343-1348.

13. Goldhar J, Penny R, Golecki JR, Hoschutzky H, Jann B, Jann K. Nonfimbrial, mannose-resistant adhesins from uropathogenic Escherichia coli $083: \mathrm{K} 1: \mathrm{H} 4$ and $014: \mathrm{K}$ ?:H11. Infect Immun 1987; 55: 1837-1842.

14. Salit IE, Gotschlich EC. Hemagglutination by purified type 1 Escherichia coli pili. J Exp Med 1977; 146: 1169-1181.

15. Johnston $\mathrm{KH}$, Gotschlich EC. Isolation and characterization of the outer membrane of Neisseria gonorrhoeae. J Bacteriol 1974; 119: 250-257.

16. Oaks EV, Hale TL, Formal SB. Serum immune response to Shigella protein antigens in Rhesus monkeys and humans infected with Shigella spp. Infect Immun 1986; 53: 57-63.

17. Westphal O, Jann K. Bacterial lipopolysaccharides: Extraction with phenol-water and further applications of the procedure. In: Whistler RL (ed) Methods in carbohydrate chemistry, vol 5. New York, Academic Press. 1965 83-91.

18. Moll A, Kusecek B, Pluschke G et al. A reexamination of the
O1 lipopolysaccharide antigen group of Escherichia coli. Infect Immun 1986; 53: 257-263.

19. Dubois M, Gilles KA, Hamilton JK, Rebers PA, Smith F. Colorimetric method for determination of sugars and related substances. Anal Chem 1956; 28: 350-356.

20. Bradford MM. A rapid and sensitive method for the quantitation of microgram quantities of protein utilizing the principle of protein-dye binding. Anal Biochem 1976; 72: 248-254.

21. Weissbach A, Hurwitz J. The formation of 2-keto-3-deoxyheptonic acid in extracts of Escherichia coli B. J Biol Chem $1959 ; 234$ : 705-709.

22. Piotrowicz BI, Edlin SE, MaCartney AC. A sensitive chromogenic limulus amoebocyte lysate micro-assay for detection of endotoxin in human plasma and in water. Zentralbl Bakteriol Mikrobial Hyg 1985; A260: 108-112.

23. Svennerholm L. Quantative estimation of sialic acids. II. A colorimetric resorcinol-hydrochloric acid method. Biochim Biophys Acta 1957; 24: 604-611.

24. Weeke B. Crossed immunoelectrophoresis. In: Axelsen NH, Krøll J, Weeke B (eds) A manual of quantitative immunoelectrophoresis. Oslo, Universitetsoforlaget, 1973; 47-56.

25. Ouchterlony Ö. Diffusion-in-gel methods for immunological analysis (II). Prog Allergy 1962; VI: 30-154

26. Mroczenski-Wildey MJ, Di Fabio JL, Cabello FC. Invasion and lysis of HeLa cell monolayers by Salmonella typhi: the role of lipopolysaccharide. Microb Pathog 1989; 6: 143152

27. Cohen PS, Rossoll R, Cabelli VJ, Yang S-L, Laux DC. Relationship between the mouse colonizing ability of a human fecal Escherichia coli strain and its ability to bind a specific mouse colonic mucous gel protein. Infect Immun $1983 ; 40: 62-69$.

28. Bradley SG. Cellular and molecular mechanisms of action of bacterial endotoxins. Annu Rev Microbiol 1979; 33: 67-94.

29. Watanabe H, Nakamura A, Timmis KN. Small virulence plasmid of Shigella dysenteriae 1 strain W30864 encodes a 41,000 -dalton protein involved in formation of specific lipopolysaccharide side chains of serotype 1 isolates. Infect Immun 1984; 46: 55-63.

30. Lindahl M, Wadström T. K99 surface hemagglutinin of enterotoxigenic $E$. coli recognizes terminal N-acetylgalactosamine and sialic acid residues of glycophorin and other complex glycoconjugates. Vet Microbiol 1984; 9: 249-257.

31. Lindahl M, Faris A, Wadström $T$. Colonisation factor antigen on enterotoxigenic Escherichia coli is a sialic-specific lectin. Lancet 1982; 2: 280.

32. Ellen RP, Fillery ED, Chan KH, Grove DA. Sialidase-enhanced lectin-like mechanism for Actinomyces viscosus and Actinomyces naeslundii hemagglutination. Infect Immun 1980; 27 : 335-343.

33. Chitnis DS, Sharma KD, Kamat RS. Role of somatic antigen of Vibrio cholerae in adhesion to intestinal mucosa. $J$ Med Microbiol 1982; 15: 53-61.

34. Cohen PS, Arruda JC, Williams TJ, Laux DC. Adhesion of a human fecal Escherichia coli strain to mouse colonic mucus. Infect Immun 1985; 48: 139-145. 